\title{
PENGARUH STRUKTUR KEPEMILIKAN TERHADAP NILAI PERUSAHAAN DENGAN PROFITABILITAS SEBAGAI VARIABEL INTERVENING STUDI PADA SEKTOR PROPERTY DAN REAL ESTATE
}

\author{
Sutrisno ${ }^{1)}$, Luky Retno Sari ${ }^{2)}$ \\ Universitas Islam Indonesia \\ sutrisno@uii.ac.id
}

\begin{abstract}
This study aims to investigate the effect of ownership on firm value with profitability as an intervening variable. The dependent variable used is $P B V$. While the independent variables used are managerial ownership and institutional ownership. The intervening variable used is ROA. The data in this study used an annual report from 18 property and real estate companies listed on the Indonesia Stock Exchange in 2014 to 2018. The data collection technique used purposive sampling technique obtained from the web www.idx.co.id and each website from the sample company. Data processing uses panel data regression and the results reveal that managerial ownership and institutional ownership have no effect on firm value. While profitability (ROA) is able to mediate institutional ownership of firm value. But profitability (ROA) is not able to mediate managerial ownership offirm value.
\end{abstract}

Keywords : managerial ownership, institutional ownership, company value, profitability

\begin{abstract}
Abstrak
Penelitian ini bertujuan untuk menginvestigasi pengaruh struktur kepemilikan terhadap nilai perusahaan dengan profitabilitas sebagai variable intervening. Variabel dependen yang digunakan adalah PBV. Sedangkan variabel independen yang digunakan adalah kepemilikan manajerial dan kepemilikan institusional. Variable intervening yang digunakan adalah ROA. Data dalam penelitian menggunakan laporan tahunan dari 18 perusahaan property dan real estate yang terdaftar di Bursa Efek Indonesia pada tahun 2014 sampai 2018. Teknik pengambilan data menggunakan teknik purposive sampling yang diperoleh dari web www.idx.co.id dan masing-masing website dari sampel perusahaan. Pengolahan data menggunakan regresi data panel dan hasilnya mengungkapkan bahwa kepemilikan manajerial dan kepemilikan institusional tidak berpengaruh terhadap nilai perusahaan. Sedangkan profitabilitas (ROA) mampu memediasi kepemilikan institusional terhadap nilai perusahaan. Tetapi profitabilitas (ROA) tidak mampu memediasi kepemilikan manajerial terhadap nilai perusahaan.
\end{abstract}

Kata kunci: kepemilikan manajerial, kepemilikan institusional, nilai perusahaan, profitabilitas 


\section{LATAR BELAKANG}

Tujuan didirikannya suatu perusahaan adalah untuk meningkatkan nilai perusahaan. Jika nilai suatu perusahaan tinggi hal itu menunjukkan bahwa pemilik perusahaan dan para pemegang saham semakin sejahtera. Menurut Hartono (2009) dalam Prastuti dan Sudiartha (2016) perusahaan itu memiliki tujuan jangka panjang yaitu dengan memaksimalkan nilai perusahaan. Nilai perusahaan merupakan salah satu factor yang akan dilihat oleh investor dalam melakukan sebuah investasi. Semakin tinggi nilai perusahaan maka akan menarik para pemegang saham untuk menanamkan dana nya, karena akan mendapatkan keuntungan yang tinggi. Selain itu pentingnya memaksimalkan nilai perusahaan adalah untuk meningkatkan kepercayaan para investor dan menunjukkan bahwa perusahaan mampu mengelola sumber daya yang dimiliki dengan baik. Hal ini sangat berdampak bagi penilaian kinerja perusahaan di masa yang akan datang.

Selain itu, agar nilai perusahaan dapat meningkat, manajemen perusahaan harus bekerjasama dengan para pemangku kepentingan (stakeholders) dan shareholders dalam mengambil suatu keputusan untuk tujuan memaksimalkan modal kerja. Akan tetapi sering terjadi sebuah perbedaan kepentingan, pihak manajer terkadang berperilaku untuk kepentingan individu sehingga menyebabkan sebuah konflik antara manajer perusahaan dengan pihak lain. Dengan kata lain konflik yang terjadi ini sering disebut konflik agensi (Senda, 2011). Menurut konsep theory of the firm (Jensen dan Meckling, 1976) tujuan perusahaan untuk meningkatkan nilai perusahaan tidak akan tercapai apabila terjadi sebuah konflik agensi.

Adapun cara untuk mengatasi terjadinya konflik agensi adalah dengan menyetarakan antara kepentingan manajerial dengan kepentingan pemilik (Imanta, 2011).
Selain itu dapat juga di minimalisir dengan cara meningkatan kepemilikan saham yang meliputi kepemilikan manajerial ataupun kepemilikan institusional. Menurut Perdana (2014) kepemilikan manajerial adalah perbandingan pemegang saham dari sisi manajer yang turut serta dalam mengambil sebuah keputusan. Kepemilikan manajerial dapat membuat perusahaan meningkatkan nilai perusahaannya. Semakin tinggi perbandingan kepemilikan manajer maka akan meningkatkan pengawasan dalam segala kegiatan di perusahaan. Dengan meningkatkan kepemilikan manajerial hal ini dapat membantu perusahaan dalam menyetarakan posisi manajer dengan pemegang saham, sehingga harapannya dapat mengurangi tindakan manajer untuk mengambil keuntungan yang berlebihan. Peningkatan manajerial juga dapat membantu menyampaikan kepentingan dari pihak pemegang saham dan pihak internal sehingga dapat menghasilkan pengambilan keputusan yang lebih baik.

Kepemilikan institusional adalah pihak yang mengawasi jalannya kinerja suatu perusahaan dan kepemilikan saham yang dimiliki oleh sebuah instansi atau lembaga tertentu (Tarjo, 2018). Kepemilikan institusional mampu menumbuhkan tingkat nilai perusahaan melalui pemanfaatan informasi dan juga mampu menangani konflik agensi karena tingginya tingkat kepemilikan institusional dapat meningkatkan pengawasan dari segala kegiatan di perusahaan. Dengan demikian jika kepemilikan institusional meningkat harapannya nilai perusahaan juga akan meningkat karena adanya pengawasan yang lebih oleh pihak pemegang saham.

Selain kepemilikan manajerial dan kepemilikan institusional factor yang dapat mempengaruhi nilai perusahaan adalah profitabilitas. Profitabilitas merupakan tingkat kemampuan perusahaan dalam 
menghasilkan keuntungan. Jika tingkat profitabilitas di suatu perusahaan tinggi maka investor akan tertarik untuk menanamkan modal nya karena dapat mengakibatkan return saham yang tinggi. Profitabilitas adalah kemampuan perusahaan dalam mendapatkan keuntungan (laba) dalam periode waktu tertentu yang diukur melalui keberhasilan perusahaan dan keahlian dalam memamnfaatkan aktifa secara produktif (munawir, 2007:33). Melihat pengertian profitabilitas tersebut bisa dikatakan bahwa profitabilitas merupakan factor yang penting dalam kelanjutan perusahaan untuk dimasa yang akan datang karena apabila profitabilitasnya tinggi maka perusahaan memiliki prospek yang baik di masa depan.

Penelitian ini dilakukan untuk mengetahui pengaruh kepemilikan manajerial dan kepemilikan institusional terhadap nilai perusahaan dengan menggunkan profitabilitas sebagai variable intervening. Dalam penelitian ini nilai perusahaan di ukur PBV profitabilitas di ukur menggunakan ROA.

\section{TeoriAgensi}

Teori agensi adalah suatu ikatan yang terjadi antara pihak pemegang saham dan manajer perusahaan. Menurut Jensen dan Meckling (1997) bahwa teori agensi merupakan suatu hubungan yang dilakukan oleh pihak principal dan pihak agen yang mana pihak principal sebagai pemegang saham dan pihak agen merupakan manajemen pengelola perusahaan. Pemegang saham mempercayai dan memberikan tanggung jawab kepada manajer untuk menjalankan perusahaan agar tujuan yang di inginkan dapat tercapai. Perusahaan memiliki salah satu tujuan untuk memaksimalkan laba bagi para pemegang saham. Sehingga manajer harus menjalankan tugas untuk kepentingan pemegang saham. Akan tetapi banyak manajer yang salah menggunakan jabatan tersebut dengan lebih mementingkan kepentingan individu atau kepentingan pribadi. Hal ini yang dapat menyebabkan konflik antara pemegang saham dan manajer. Karena akan mempengaruhi harga saham dan mengakibatkan turunnya laba serta nilai perusahaan.

Menurut Anthony, Robert N, and Govindarajan (2011) komponen dari teori agensi salah satunya yaitu perbedaan kepentingan diantara principal dan agent. Pihak agent akan beranggapan bahwasannya manajer akan memberikan mereka tidak hanya sebatas financial tetapi juga adanya lingkungan kerja yang baik dan tidak membosankan atau bahkan jam kerja yang fleksibel. Akan tetapi berbeda dengan apa yang akan dipikirakan oleh pihak principal, mereka hanya akan peduli dengan tingkat pengembalian dana yang mereka investasikan seberapa besar keuntungan yang akan mereka dapatkan. Hal ini yang dapat memicu terjadinya konflik kepentingan diantara pihak agent dan principal.

\section{Teori Signal}

Teori signal adalah konsep teori yang digunakan untuk menyampaikan sebuah informasi kepada pasar guna untuk memberikan sinyal, baik itu sinyal positif atau pun sinyal negative sehingga pasar bisa menilai perusahaan mana yang memilki kualitas baik dan buruk. Menurut Brigham dan Huston (2012) teori signal merupakan sebuah sikap yang diterapkan oleh manajemen dalam memberikan arahan kepada investor mengenai bagaimana manajemen dalam melihat perkembangan perusahaan dimasa yang akan datang. Teori ini juga dapat membantu perusahaan dalam melihat perbedaaan perusahaan yang memiliki nilai perusahaan yang tinggi dan rendah. Jika perusahaan memiliki tingkat profitabilitas yang tinggi maka nilai perusahaan juga meningkat karena kemampuan 
perusahaan dalam menghasilkan keuntungannya tinggi, sebaliknya jika profitabilitas perusahaan rendah maka nilai perusahaan juga rendah.

\section{Nilai Perusahaan}

Perusahaan memiliki tujuan yaitu untuk memaksimalkan nilai perusahaan. Nilai perusahaan merupakan suatu nilai yang menggambarkan kondisi perusahaan. Apabila nilai perusahaan tinggi, maka para pemegang saham perusahaan tersebut memiliki tingkat kesejahteraan yang tinggi pula. Semakin tinggi nilai perusahaan maka semakin makmur para pemegang saham dan tujuan dari perusahaan pun tercapai. Menurut Listiyowati dan Indarti (2018) mengatakan bahwasannya nilai perusahaan adalah sebuah pandangan investor kepada perusahaan dan sering dihubungkan dengan harga saham. Jika harga saham tinggi akan meningkat nilai perusahaan. Nilai perusahaan yang tinggi juga dapat digambarkan dengan tingkat pengembalian investasi yang tinggi. Hal ini sangat berdampak bagi perusahaan karena pasar akan menilai bahwa perusahaan memiliki kinerja yang baik dan memilki prospek dimasa yang akan datang.

Dalam penelitian ini nilai perusahaan di ukur menggunakan price book value (PBV). Price book value merupakan suatu perbandingan antara harga saham dengan nilai buku perusahaan. Semakin tinggi price book value sebuah perusahaan menunjukkan tingkat kemakmuran pemegang saham, dan tujuan utama perusahaan adalah dapat memakmurkan pemegang saham (Sukirni, 2012).

\section{Kepemilikan Manajerial}

Menurut penelitian (Sukirni, 2012) kepemilikan manajerial merupakan kumpulan pemegang saham sekaligus sebagai pemilik perusahaan dari pihak manajemen yang turut serta dalam pengambilan keputusan di perusahaan. Kepemilikan manajerial adalah kepemilikan saham manajemen atau para pengelola perusahaan seperti dewan direksi, komisaris serta karyawan perusahaan. Manajer dalam hal ini memegang peranan penting karena manajer melaksanakan empat fungsi manajemen serta pengambil keputusan. Besarnya perbandingan kepemilikan manajer nantinya mampu untuk mengawasi setiap kegiatan-kegiatan yang dilakukan di dalam perusahaan. Perbandingan jumlah kepemilikan manajerial di perusahaan dapat menandakan bahwa terdapat kepentingan yang sama diantara pemegang saham dan manajer (Puspaningrum, 2017).

\section{Kepemilian Institusional}

Menurut Sukirni (2012) kepemilikan institusional merupakan saham perusahaan yang dimiliki oleh sebuah instansi atau lembaga keuangan seperti perusahaan asuransi, bank, perusahaan investasi dan kepemilikan institusi lain. Kepemilikan institusional memiliki peran yang penting dalam mengontrol manajemen karena dapat memajukan peningkatan pengawasan yang optimal. Tingginya kepemilikan institusional akan mengakibatkan pengendalian yang lebih besar oleh pihak investor institusional sehingga mampu membendung perilaku opportunistic manajer. Semakin tinggi kepemilikan institusional maka pengawasan akan lebih efektif. Jika pengawasan di dalam perusahaan baik maka akan berdampak juga terhadap kemakmuran pemegang saham.

\section{Profitabilitas}

Profitabilitas adalah kemampuan perusahaan memperoleh laba dalam hubungannya dengan penjualan, total aktiva maupun modal sendiri (Wida, 2014). Profitabilitas menunjukkan kesuksesan perusahaan dalam memperoleh keuntungan. Tingginya tingkat profitablitias suatu perusa- 
haan membuktikan bahwa kemakmuran pemegang saham akan meningkat. Profitabilitas yang tinggi dapat dikatakan bahwa pengelolaan perusahaan berjalan dengan baik dan efektif. Profitabilitas merupakan salah satu pengukuran yang digunakan dalam melihat seberapa basar perusahaan mampu mendapatkan keuntungan. Jika profitabilitas di suatu perusahaan tinggi maka akan menjadi incaran para investor karena akan memberikan keuntungan yang tinggi dari investasi yang telah mereka berikan di perusahaan tersebut. Profitabilitas sangat penting karena hal itu menunjukkan seberapa besar prospek perusahaan tersebut untuk di masa yang akan datang dan bagaimana perusahaan dapat mempertahankan perusahaan untuk waktu yang lama.

\section{METODE PENELITIAN \\ Populasi dan Sampel}

Populasi yang diambil dalam penelitian ini yaitu semua perusahaan property dan real estate yang terdaftar di BEI selama periode 2014 - 2018. Sedangkan sample pada penelitian sebanyak 18 perusahaan dengan metode purposive sampling.

\section{Variabel Penelitian}

Variabel penelitian terdiri dari satu variabel dependen yakni nilai perusahaan yang diukur denga price to book value ratio (PBV), satu variabel intervening yakni profitabilitas yang dikur dengan return on assets (ROA), dan dua variabel independen terdiri dari kepemilikan manajerial dan kepemilikan institusi. Berkut ini adalah variabel dan pengukuran variabelnya:

Tabel 1: Variabel dan Pengukuran Variabel

\begin{tabular}{|c|c|c|c|}
\hline No & Variabel & Notasi & Pengukuran \\
\hline 1 & Nilai Perusahaan & PBV & Harga saham/ nilai buku \\
\hline 2 & Profitabilitas & ROA & Laba Setelah Pajak/Total Aset \\
\hline 3 & Kepemilikan Manajerial & KM & $\begin{array}{l}\text { Jumlah saham manajer/Jumlah saham } \\
\text { beredar }\end{array}$ \\
\hline 4 & Kepemilikan Institusi & $\mathrm{KI}$ & $\begin{array}{l}\text { Jumlah saham } \\
\text { beredar }\end{array}$ \\
\hline
\end{tabular}

\section{HASIL DAN PEMBAHASAN} Statistik Deskriptif

Hasil dari statistik deskriptif akan menunjukkan perhitungan terhadap nilai minimum, nilai maksimum, median dan mean dari suatu data.

Tabel 2: Statistik Deskriptif

\begin{tabular}{llllll}
\hline Variabel & Min & Max & Median & Mean & Observation \\
\hline PBV & 0.153 & 7.604 & 1.025 & 1.439 & 90 \\
KM & 0.000 & 0.646 & 0.001 & 0.036 & 90 \\
KI & 0.008 & 0.914 & 0.653 & 0.561 & 90 \\
ROA & -0.055 & 0.181 & 0.036 & 0.047 & 90 \\
\hline
\end{tabular}

Dari tabel 2 dapat disimpulkan bahwa variable Price Book Value (PBV) dengan nilai minimum sebesar 0.153 dari semua sample penelitian diperoleh oleh perusahaan
Greenwood Sejahtera Tbk pada tahun 2015. Untuk nilai maksimum dengan nilai sebesar 7.604 pada tahun 2017 diperoleh oleh perusahaanMetropolitan Kentjana Tbk. Nilai 
median dari keseluruhan sample sebesar 1.025 sedangkan untuk nilai mean dari seluruh sample penelitian didapatkan nilai sebesar 1.439. Untuk nilai minimum variable kepemilikan manajerial menunjukkan nilai sebesar 0.000 dari 18 sample perusahaan nilai tersebut di peroleh oleh 6 perusahaan. Nilai maksimum sebesar 0.646 di peroleh oleh perusahaan Pickoland Development Tbk pada tahun 2017 dan 2018. Nilai median dari seluruh sample sebesar 0.001 sedangkan nilai mean dari seluruh sample sebesar 0.036. Variable kepemilikan institusional menunjukkan nilai minimum sebesar 0.008 dan diperoleh oleh perusahaan Pickoland Development
Tbk pada tahun 2018. Nilai maksimum sebesar 0.914 diperoleh oleh perusahaan Dadanayasa Arthatama Tbk pada tahun 2017 dan 2018. Untuk nilai median dari seluruh sample penelitian didapatkan nilai sebesar 0.653 sedangkan nilai mean sebesar 0.561 .

Pada variable Return on Asset (ROA) nilai minimum nya sebesar -0.055 pada tahun 2017 yang diperoleh oleh perusahaan Bukit Darmo Property Tbk. Nilai maksimum sebesar 0.181 dan diperoleh oleh perusahaan Metropolitan Kentjana Tbk pada tahun 2016. Nilai median yang didaptkan sebesar 0.036 dari seluruh sample penelitian sedangkan nilai mean nya sebesar 0.047

\section{Uji T (Uji Hipotesis)}

Tabel 2 Rekapitulasi Hasil Uji Hipotesis

\begin{tabular}{cccc}
\hline Variabel & $\beta$ & Prob. & Keterangan \\
\hline KM & -0.111 & 0.2307 & H-1 tidak diterima \\
KI & -0.017 & 0.7189 & H-2 tidak diterima \\
KM & -0.790 & 0.7201 & H-3 tidak diterima \\
KI & -1.637 & 0.1525 & H-4 tidak diterima \\
ROA & 11.502 & 0.0002 & H-5 diterima \\
KMxROA & -0.213 & 0.9951 & H-6 tidak diterima \\
KIxROA & 16.526 & 0.0018 & H-7 diterima \\
\hline
\end{tabular}

\section{PEMBAHASAN}

\section{Pengaruh Kepemilikan Manajerial ter- hadap Profitabilitas}

Dalam hasil uji regresi yang telah dilakukan bisa disimpulkan bahwa nilai koefisien dengan variable kepemilikan manajerial memiliki nilai sebesar -0.111 dan nilai probabilitas $0.2307>0.05$ yang memiliki makna bahwa kepemilikan manajerial tidak memiliki pengaruh terhadap profitabilitas. Hasil penelitian ini menjelaskan bahwa proporsi kepemilikan manajerial yang cenderung sedikit, sehingga penerapan kepemilkan manajerial dalam membantu menyatukan kepentingan antara manajerial dan pemilik agar meningkatkan kinerja belum berjalan efektif. Hal tersebut menandakan adanya kepemilikan manajerial dalam perusahaan masih belum mampu menyeimbangkan kepentingan pemegang saham diluar manajeman. Dalam kondisi ini dapat menimbulkan konflik keagenan dan dapat memicu manajemen menggunakan utilitasnya untuk mencari keuntungan sendiri, tanpa memikirkan kerugian yang diterima pemegang saham lainnya. Hasil penelitian ini dapat mengindikasikan bahwa kepemilikan saham oleh manajemen bukan merupakan salah satu faktor yang bisa mempengaruhi profitabilitas. Besarnya proporsi saham pihak manajemen masih belum bisa mengurangi konflik keagenan dalam perusahaan. Oleh 
karena itu, tinggi rendahnya kepemilikan saham oleh manajemen belum dapat menunjukkan tinggi rendahnya nilai profitabilitas suatu perusahaan.

Hasil dari peneilitian ini sejalan dengan penelitian yang dilakukan oleh Wiranata dan Nugrahanti (2013) yang menyatakan tidak ada pengaruh antara kepemilikan manajerial terhadap profitabilitas. Namun tidak sejalan dengan penelitian yang dilakukan oleh Fauzi dan Musallam (2015) yang menyatakan bahwa terdapat pengaruh negatif dan signifikan dari kepemilikan manajerial terhadap profitabilitas.

\section{Pengaruh Kepemilikan Institusional terhadap Profitabilitas}

Berdasarkan dari hasil uji regresi yang telah dilakukan menyatakan bahwa kepemilikan institusional tidak berpengaruh terhadap profitabilitas dikarenakan nilai koefisien menunjukkan hubungan yang negative sebesar -0.017 dan nilai probabilitas $0.7189>0.05$ sehingga hipotesis ini tidak diterima. Hasil ini menunjukkan tinggi rendahnya kepemilikan institusional tidak berpengaruh terhadap kinerja keuangan dikarenakan terdapat asimetri informasi diantara pemegang saham dengan manajer mengakibtakan manajer yang berperan dalam mengelola perusahaan bisa mengendalikan perusahaan karena mempunyai informasi yang lebih tentang perusahaan jika dibandingkan dengan pemegang saham. Sehingga adanya kepemilikan institusi belum menjamin proses monitoring terhadap manajer akan berjalan dengan efektif sehingga tidak berpengaruh terhadap kinerja keuangan.

Hasil penelitian ini sejalan dengan penelitian yang dilakukan oleh Mollah, Farooque, dan Karim (2012) yang membuktikan bahwasannya kepemilikan institusional tidak berpengaruh terhadap profitabilitas. Tetapi tidak sejalan dengan penelitian Kumai, Love dan Kabiru (2014) yang menyimpulkan bahwasannya kepemilikan institusional memiliki pengaruh positif signifikan terhadap ROA.

\section{Pengaruh Kepemilkan Manajerial terhadap Nilai Perusahaan}

Hasil dari uji regresi terhadap variable kepemilikan manajerial menunjukkan nilai koefisien sebesar -0.790 dengan probabilitas sebesar $0.7201>0.05$ karena nilai probabilitas lebih besar dibandingkan dengan nilai signifikansi yang telah ditentukan maka kepemilikan manajerial tidak berpengaruh terhadap nilai perusahaan. Dalam hasil penelitian ini dapat dikatakan bahwa kepemilikan manajerial belum mampu mengurangi masalah keagenan. Proporsi kepemilikan manajerial yang besar tidak mampu menyetarakan kepentingan manajemen dan pemegang saham, sehingga tujuan perusahaan dalam mencapai nilai perusahaan yang tinggi tidak dapat tercapai. Para manajer memiliki kepentingan pribadi yang ingin dipenuhinya dibandingkan dengan pencapaian tujuan perusahaan secara menyeluruh.

Hasil penelitian ini sejalan dengan penelitian yang dilakukan oleh Garcia dan Sanchez (2013) dan Chilin (2007) yang membuktikan tidak adanya hubungan yang berpengaruh antara kepemilikan manajerial terhadap nilai perusahaan. Namun hasil penelitian ini tidak sejalan dengan penelitian yang dilakukan oleh Sun, Ding, Guo, dan Li (2016) yang menunjukkan bahwa kepemilikan manajerial berpengaruh positif terhadap nilai perusahaan.

\section{Pengaruh Kepemilikan Institusional terhadap Nilai Perusahaan}

Berdasarkan hasil regresi nilai koefisien pada variable kepemilikan institusional sebesar -1.637 dengan besarnya nilai probabilitas yaitu $0.1525>0.05$, dikarenakan nilai tersebut lebih besar dari nilai 
signifikansi maka kepemilikan institusional tidak dapat berpengaruh terhadap nilai perusahaan. Hal ini dikarenakan pihak institusi tidak dapat secara efektif mengawasi manajemen. Hal tersebut dapat terjadi karena adanya asimetri informasi antara pemegang saham dan manajemen, sehingga manajemen dapat mengendalikan perusahaan sesuai keinginan mereka. Asimetri informasi ini merupakan kendala bagi lembaga dalam mengawasi perilaku manajemen, karena informasi yang dipegang oleh lembaga tidak sebaik informasi yang dipegang oleh manajemen, sehingga lembaga mengalami kesulitan dalam mengendalikan perilaku manajemen. Dengan demikian kepemilikan institusional tidak memiliki dampak pada nilai perusahaan.

Hasil penelitian ini sejalan dengan penelitian yang dilakukan oleh Pertiwi dan Hermanto (2017) menyatakan bahwa kepemilikan institusional tidak mempengaruhi nilai perusahaan. Akan tetapi hasil penelitian ini tidak selaras dengan penelitian yang dilakukan oleh Navissi dan Naiker (2010) yang menyatakan bahwasannya kepemilikan institusional memiliki pengaruh terhadap nilai perusahaan.

\section{Pengaruh Profitabilitas terhadap Nilai Perusahaan}

Hasil regresi menunjukkan nilai koefisien pada variable profitabilitas sebesar 11.502 yang berarti memilki hubungan yang positif, dengan nilai probabilitas lebih kecil dari nilai signifikansi yang telah ditentukan yaitu $0.0002<0.05$. Hal ini dapat diartikan bahwa profitabilitas memiliki pengaruh positif yang signifikan terhadap nilai perusahaan. Profitabilitas memberikan indikasi yang luas bahwasannya perusahaan memiliki kemampuan untuk meningkatkan tingkat pendapatan. Profitabilitas mempengaruhi nilai perusahaan karena nilai perusahaan memiliki pandangan positif terhadap pencapaian laba dalam melakukan pembayaran dividen, sehingga harga saham akan meningkat karena perusahaan menunjukkan sinyal positif untuk membayar dividen. Semakin besar profitabilitas perusahaan, semakin banyak keuntungan yang diberikan kepada pemegang saham, sehingga nilai perusahaan diharapkan menjadi lebih tinggi. Investor percaya bahwa perusahaan dengan profitabilitas yang tinggi memiliki peluang besar untuk membayar dividen dan memiliki kesempatan untuk mendanai proyek investasi secara internal. Akibatnya, investor semakin tertarik untuk membeli saham perusahaan sehingga nilai perusahaan akan meningkat juga.

Hasil penelitian ini sejalan dengan penelitian yang dilakukan oleh Sucuahi dan Cambarihan (2016) dan Kodithuwakku (2016) mereka menyatakan bahwasannya profitabilitas memiliki pengaruh positif terhadap nilai perusahaan. Akan tetapi hasil penelitian ini tidak sejalan dengan penelitian yang dilakukan oleh Chaidir (2015) yang menyatakan bahwa ROA tidak mempengaruhi nilai perusahaan.

\section{Pengaruh Kepemilikan Manajerial ter- hadap Nilai Perusahaan melalui Profi- tabilitas sebagai variable intervening}

Berdasarkan dari hasil uji regresi untuk hipotesis keenam ini nilai koefisien ditunjukkan sebesar -0.213 dengan nilai probabilitas $0.9951>0.05$ hal ini bisa disimpulkan bahwa profitabilitas sebagai variable intervening tidak mampu memediasi kepemilikan manajerial terhadap nilai perusahaan karena nilai probabilitas yang ditunjukkan lebih besar dari nilai signifikansi yang telah ditentukan. Hal ini bisa diartikan bahwa perusahaan dengan profitabilitas yang tinggi belum tentu menarik perhatian manajemen untuk menambah kepemilikan saham. Manajemen kemungkinan beranggapan bahwa keuntungan dari perusahaan 
akan dinikmati oleh pemegang saham selain manajer, sehingga manajer yang memiliki saham tidak dapat menikmati keuntungan yang diperoleh perusahaan. Hal inilah yang menimbulkan konflik keagenan, manajer melakukan tindakan yang menguntungkan diri mereka sendiri karena perbedaan kepentingan dengan pihak principal. Sehingga menimbulkan biaya keagenan dan ada kemungkinan mekanisme pengawasan yang dilakukan serta tinggimya biaya keagenan yang dikeluarkan perusahaan tidak diiringi dengan kinerja keuangan yang baik sehingga tidak bisa meningkatkan nilai perusahaan. Hasil ini juga mengindikasikan bahwa proporsi kepemilikan manajerial yang tinggi tidak bisa menjamin kinerja keuangan yang baik dan belum tentu bahwa investor dalam meninvestasikan modalnya melihat kinerja perusahaan tersebut baik berdasarkan tingkat profitabilitas. Ada kemungkin faktorfaktor lain yang mempengaruhi nilai perusahaan seperti leverage, ukuran perusahaan, dan kualitas laba di perusahaan tersebut.

Hasil dari penelitian ini sejalan dengan penelitian yang dilakukan oleh Julianti (2015) bahwa profitabilitas tidak bisa memediasi kepemilikan manajerial terhadap nilai perusahaan.

\section{Pengaruh Kepemilikan Institusional terhadap Nilai Perusahaan melalui Profitabilitas sebagai variabel intervening}

Dari hasil uji regresi nilai koefisien yang ditunjukkan sebesar 16.526 yang berarti memiliki arah hubungan yang positif dengan nilai probabilitas sebesar $0.0018<0.05$ karena nilai tersebut lebih kecil dari signifikansi yang telah ditentukan maka dapat dikatakan bahwa profitabilitas sebagai variable intervening mampu memediasi kepemilikan institusional terhadap nilai perusahaan. Hasil dari penelitian ini menunjukkan bahwa profitabilitas mampu membuat kepemilikan institusional berpengaruh terhadap nilai perusahaan dikarenakan jika profitabilitas diperusahaan tersebut meningkat akan menarik para lembaga atau institusi untuk meningkatkan kepemilikan saham karena jika profitabilitas tinggi itu merupakan sebuah tanda bagi para investor untuk menanamkan modal. Jika keinginan investor tinggi terhadap saham perusahaan maka harga saham ikut meningkat dan itu juga akan berpengaruh dengan tingginya nilai perusahaan. Hasil dari penelitian ini sejalan dengan penelitian yang dilakukan oleh Yanto (2018) bahwa profitabilitas bisa memediasi keepemilikan institusional terhadap nilai perusahaan, akan tetapi tidak sejalan dengan penelitian yang dilakukan oleh Wardani dan Hermuningsih (2011) yang menyimpulkan bahwa kinerja keuangan tidak mampu memdiasi hubungan antara kepemilikan institusional dengan nilai perusahaan.

\section{PENUTUP \\ Simpulan}

Berdasarkan hasil pengujian pemilihan model regresi diambil kesimpulan bahwasannya model regresi data panel pada penelitian ini menggunakan random effect, untuk persamaan pertama dengan profitabilitas (ROA) sebagai variable dependen. Hasil penelitian menunjukkan bahwa kepemilikan manajerial dan kepemilikan institusional tidak memiliki pengaruh terhadap profitabilitas. Besar kecilnya proporsi kepemilikan tersebut belum membuktikan bisa meningkatkan profitabilitas.

Hasil penelitian menunjukkan dengan nilai perusahan (PBV) sebagai variable dependen kepemilikan manajerial dan kepemilikan institusional tidak berpengaruh terhadap nilai perusahaan. Besarnya kepemilikan manajerial belum menjamin kinerja yang dilakukan akan baik sahingga belum tentu dapat meningkatkan nilai 
perusahaan. Selain itu besarnya proporsi kepemilikan institusional juga belum menjamin bahwa institusi atau lembaga dapat mengawasi kinerja manajemen secara efektif. Sedangkan untuk variable profitabilitas menunjukkan hasil yang berbeda. Profitabilitas (ROA) memiliki pengaruh positif yang signifikan terhadap nilai perusahaan. Tingginya profitabilitas suatu perusahaan menjadi sebuah sinyal yang baik bagi para investor untuk berinvestasi sehingga hal itu dapat meningkatkan nilai perusahaan.

\section{Saran}

Hasil penelitian dengan nilai perusahaan (PBV) sebagai variabel dependen serta profitabilitas (ROA) sebagai variable intervening menunjukkan hasil bahwa profitabilitas tidak mampu memediasi kepemilikan manjerial terhadap nilai perusahaan. Sedangkan untuk kepemilikan institusional, profitabilitas mampu memediasi terhadap nilai perusahaan.

Berdasarkan hasil penelitian tersebut diharapkan bisa dimanfaatkan oleh manajemen perusahaan dalam meningkatkan nilai perusahaan. Variabel yang sangat menentukan dalam meningkatkan nilai perusahaan adalah profitabilitas yang diukur dengan ROA. Sementara struktur kepemilikan yang terdiri kepemilikan manajerial tidak berpengaruh terhadap nilai perusahaan, dan ini tentunya tidak sesuai dengan tujuan didorongnya kepemilikan manajerial dalam rangka mendorong tercapainya tujuan perusahaan meningkatkan nilai perusahaan. Kepemilikan manajerial dimaksudkan agar para manajer perusahaan merasa ikut memiliki perusahaan sehingga bekerja dengan sebaik-baiknya. Demikian pula dengan kepemilikan institusi dimaksudkan agar bisa melakukan monitoring terhadap kinerja perusahaan. Namun demikian kepemilikan institusi masih baik karena bisa meningkatkan nilai perusahaan melalui profitabilitas.

Penelitian selanjutnya diharapkan bisa menggunakan sample dan data yang lebih banyak agar lebih mendukung penelitian serta periode pengamatan yang lebih lama. Karena dalam penelitian ini hanya terdapat 18 sample yang memenuhi kriteria sehingga dengan banyaknya sample diharapakan bisa mendapatkan hasil penelitian yang lebih lengkap. Selain itu karena pada penelitian ini profitabilitas hanya diukur melalui ROA untuk penelitian selanjutnya bisa menambahkan variable lain serta faktorfaktor lain yang bisa mempengaruhi nilai perusahaan.

\section{DAFTAR PUSTAKA}

Anthony, Robert, N., \& Govindarajan. (2011). Sistem Pengendalian Manajemen. Edisi 12. Jakarta: Salemba Empat.

Chaidir. (2015). Pengaruh Struktur Modal, Profitabilitas dan Pertumbuhan Perusahaan terhadap Nilai Perusahaan pada Perusahaan Sub Sektor Transportasi yang tercatat di Bursa Efek Indonesia Periode 2012-2014. Jurnal Ilmiah Manajemen Fakultas Ekonomi. 1(2), 1-21.

Chilin, Grace M, \& Liao. (2007). Ownership Structure, Information Disclosure and Corporate Value: An Empirical Analysis of Taiwan Companies. Proceedings of the 13 Asia Pacific Management Conference, Melbourne, Australia, 698-704.

Fauzi, H., \& Musallam, S. (2015). Corporate Ownership and Company Performance: a study of Malaysian listed companies. Social Responsibility Journal, 11(3), 439-448 http://doi. org/10.1108/SRJ-05-2014-0064. 
Garcia, M., \& Sanchez, B. (2013). Firm Value and Ownership Structure in the Spanish Capital Market. Corporate Governance; The International Journal of Business in Society, 11(1), 41-53 http:// doi.org/10.1108/14720701111108835.

Herpraningsih, W., \& Makhdalena, G. (2019). Influence of Managerial Ownership of Profitability and Its Impact on The Company'sValue in Manufacturing Companies Listed on Indonesia Stock Exchange (IDX) Period 2015 to 2017. JOM FKIP-UR, Vol 6(2), 1-13.

Imanta, D. (2011). Faktor-Faktor yang Memengaruhi Kepemilikan Managerial. Jurnal Bisnis dan Akuntansi, 13 (1), 67-80.

Jensen, M., \& Meckling, W. (1976). Theory of the firm: Managerial behavior,agency costs and ownership structure. Journal of Financial Economics, Vol 3(4), 305-360.

Julianti, D. (2015). Pengaruh Mekanisme Good Corporate Governance terhadap Nilai Perusahaan dengan Profitabilitas Sebagai Variabel Intervening pada Perusahaan Manufaktur yang Terdaftar di Bursa Efek Indonesia Tahun 20102013. Universitas Negeri Semarang.

Kodithuwakku, S. (2016). Impact of Firm Specific Factors on the Stock Prices: A Case Study on Listed Manufacturing Companies in Colombo Stock Exchange. International Journal for Research in Business, Management and Accounting. ISSN:2455-6114. Vol 2 Issue 3.

Kumai, B., Love O, \& Kabiru, I. (2014). The Impact of ownership Structure on the Financial Performance of Listed Insurance Firms in Nigeria. International Journal of Academic Research in Accounting, Finance and Management Sciences, 4(1), 409-416.
Listiyowati, \& Indarti, I. (2018). Analisis Pengaruh Good Corporate Governance Terhadap Nilai Perusahaan dengan Profitabilitas Sebagai Variabel Intervening (Studi Empiris Pada Perusahaan Kontruksi yang Terdaftar di BEI tahun 2014-2017. Jurnal Sosial Ekonomi dan Humaniora (JSEH), ISSN: 2461-0666, Vol 4 (2), 1-16.

Maryanto, H. (2017). Pengaruh Intellectual Capital dan Good Corporate Governance Terhadap Nilai perusahan dengan Kinerja Keuangan Sebagai Variabel Intervening Pada perusahaan Manufaktur di Bursa Efek Indonesia Tahun 2011-2014. JOM Fekon, Vol 4 (1), 1598-1612.

Mollah, S., Al Farooque, O., \& W, K. (2012). Ownership Structure, Corporate Governance and Firm Performance; Evidence from an African Emerging Market. Studies in Economicsand Finance, 29(4), 301-319 http://doi.org/ 10.1108/10867371211266937.

Navissi, F., \& Naiker, V. (2010). Institutional Ownership and Corporate Value. Managerial Finance, 32(3), 247-258. http://doi.org/10.1108/0307435061064 6753.

Ngatemin, Maksum, A., Erlina, \& Sirojuzilam. (2018). Effect of Institutional Ownership and Profitability to Firm Value with the Capital Structure as Intervening Variable (Emprical Study at Company Tourism Industry Sector Listed in Indonesia). International Journal of Civil Engineering and Technology (IJCIET), Vol 9 (5), 1305-1320.

Perdana, R. S. (2014). Analisis Pengaruh Corporate Governance Terhadap Nilai Perusahaan. skripsi. Semarang: Universitas Diponegoro. 
Pertiwi, S., \& Hermanto, S. (2017). Pengaruh Struktur Kepemilikan, Kebijakan Dividen, Hutang dan Profitabilitas terhadap Nilai Perusahaan. Jurnal Ilmu dan Riset Akuntansi 6(7), 1-23.

Prastuti, N., \& Sudiartha, I. (2016). Pengaruh Struktur Modal, Kebijakan Dividen, dan Ukuran Perusahaan terhadap Nilai Perusahaan pada Perusahaan Manufaktur. E-Jurnal Manajemen Unud, 5(3), 1572-1598.

Puspaningrum, Y. (2017). Pengaruh Corporate Social Responsibility dan Kepemilikan Manajerial Terhadap Nilai Perusahaan dengan Profitabilitas dan Ukuran Perusahaan Sebagai Variabel Moderating (Studi Empiris Pada Perusahaan Pertambangan Di Bursa Efek Indonesia. Jurnal Profita Edisi 2, 2-14.

Senda, F. D. (2011). Pengaruh Kepemilikan Manajerial, KepemilikanInstitusional, Kebijakan Deviden, Profitabilitas, Leverage Financial, dan Investment Opportunity Set Terhadap Nilai Perusahaan. Jurnal Manajemen Fakultas Ekonomi Universitas Diponegoro Semarang.

Sucuahi, W., \& Jay Mark Cambarihan. (2016). Influence of Profitability to the Firm Value of Diversified Companies in the Philippines. Accounting and Finance Research, Vol 5, No 2.

Sukirni, D. (2012). Kepemilikan Manajerial,Kepemilikan Institusional, Kebijakan Deviden dan Kebijakan Hutang Analisis Terhadap Nilai Perusahaan. Accounting Analysis Journal, Vol 1 (2), 2-12.

Sun , J., Ding, L., Guo, J., \& Li, Y. (2016). Ownership, Capital Structure and Financing Decision:Evidence from the UK. The British Accounting Review,
48(4), 448-463 https://doi. org/10.1016/j.bar.2015.04.001.

Tarjo. (2008). Pengaruh Konsentrasi Kepemilikan Institusional dan Leverage Terhadap Manajemen Laba, Nilai Pemegang saham serta Cost of Equity Capital. Simposium Nasioanal Akuntansi XI, Pontianak.

Wardani, D., \& Hermuningsih, S. (2011). Pengaruh Struktur Kepemilikan Terhadap Nilai Perusahaan Dengan Kinerja Keuangan dan Kebijakan Hutang Sebagai Variabel Intervening. Jurnal Siasat Bisnis 15(1), 27-36.

Wida, N., \& Suartana, I. (2014). Pengaruh Kepemilikan Manajerial dan Kepemilikan Institusional Pada Nilai Perusahaan. E-Jurnal Akuntansi Universitas Udayana, 9.3, 575590.

Wiranata, Y. A. (2013). Pengaruh Struktur Kepemilikan Terhadap Profitabilitas Perusahaan Manufaktur di Indonesia. Jurnal Akuntansi dan Keuangan, Vol. 15, No. 1, 15-26.

Wijaya, B. \&. (2015). Pengaruh Profitabilitas Terhadap Nilai Perusahaan (Kebijakan Dividen Dan Kesempatan Investasi Sebagai Variabel Mediasi). E-Jurnal Manajemen Unud, Vol 4(12), 4477-4500.

Wulandari, I. S. (2012). Faktor-Faktor yang Mempengaruhi Struktur Modal Perusahaan Manufaktur yang Terdaftar di Bursa Efek Indonesia. Skripsi. Universitas Negeri Yogyakarta.

Yanto, E. (2018). Effect of Corporate Social Responsibility and Good Corporate Governance on the Value of Company with Profitability as Moderating Variables. JAAF (Journal of Applied Accounting and Finance), Vol 2(1), $36-49$. 